\title{
First record of Pseudoidium sp. on Heterophragma quadriloculare in India
}

\section{Thite SV, Kore BA *}

Department of Botany, Yashvantrao Chavan Institute of Science, Satara - 415 001, (M.S), India

Corresponding author E-mail: basavaraj.kore@rediffmail.com

Thite SV, Kore BA 2017 - First record of Pseudoidium sp. on Heterophragma quadriloculare in India. Plant Pathology \& Quarantine 7(2), 106-108, Doi 10.5943/ppq/7/2/3

\begin{abstract}
In September 2013, severe powdery mildew symptoms were observed on the leaves of Heterophragma quadriloculare (Bignoniaceae). Based on morphological characters the pathogen was identified as Pseudoidium sp. This is the first record of Pseudoidium sp. on H. quadriloculare in India.
\end{abstract}

Key words - Bignoniaceae - Erysiphales - Erysiphe - Heterophragma quadriloculare Pseudoidium

\section{Introduction}

Heterophragma quadriloculare is a large deciduous tree that is widely distributed in Madhya Pradesh, Gujarat, Maharashtra, Andhra Pradesh, and Karnataka. Various parts of this plant are traditionally used in rural areas as an anti-diabetic, night emission, antidote, and for its antimicrobial activity and antifungal activity.

The occurrence of powdery mildew in its anamorph stage on $H$. quadriloculare was first

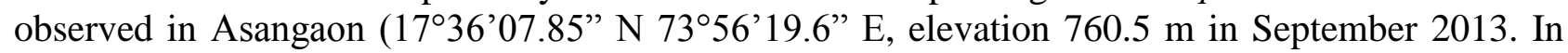
March 2014, the pathogen was also found in the ranges of hills viz. Yavateshwar $\left(17^{\circ} 41^{\prime} 02.91^{\prime \prime} \mathrm{N}\right.$ $73^{\circ} 56^{\prime} 58.15^{\prime \prime}$ E, elevation $1042.1 \mathrm{~m}$ ) and Varoshi $\left(17^{\circ} 52^{\prime} 04.42^{\prime \prime} \mathrm{N} 73^{\circ} 45^{\prime} 03.12^{\prime \prime}\right.$ E, elevation $863.08 \mathrm{~m})$.

\section{Materials and Methods}

Infected leaves were collected and symptoms were examined by light microscopy. A reference specimen has been deposited in Ajrekar Mycological Herbarium at Agharkar Research Institute, Pune (M.S.) India (accession no. AMH-9615).

\section{Results}

Symptoms included greyish white powdery growth consisting of epiphytic mycelia and conidia mostly on adaxial surface of the leaves (Fig. 1a, b). Symptoms on the abaxial surface were less conspicuous and older leaves were more susceptible. Severely infected plants were defoliated. 

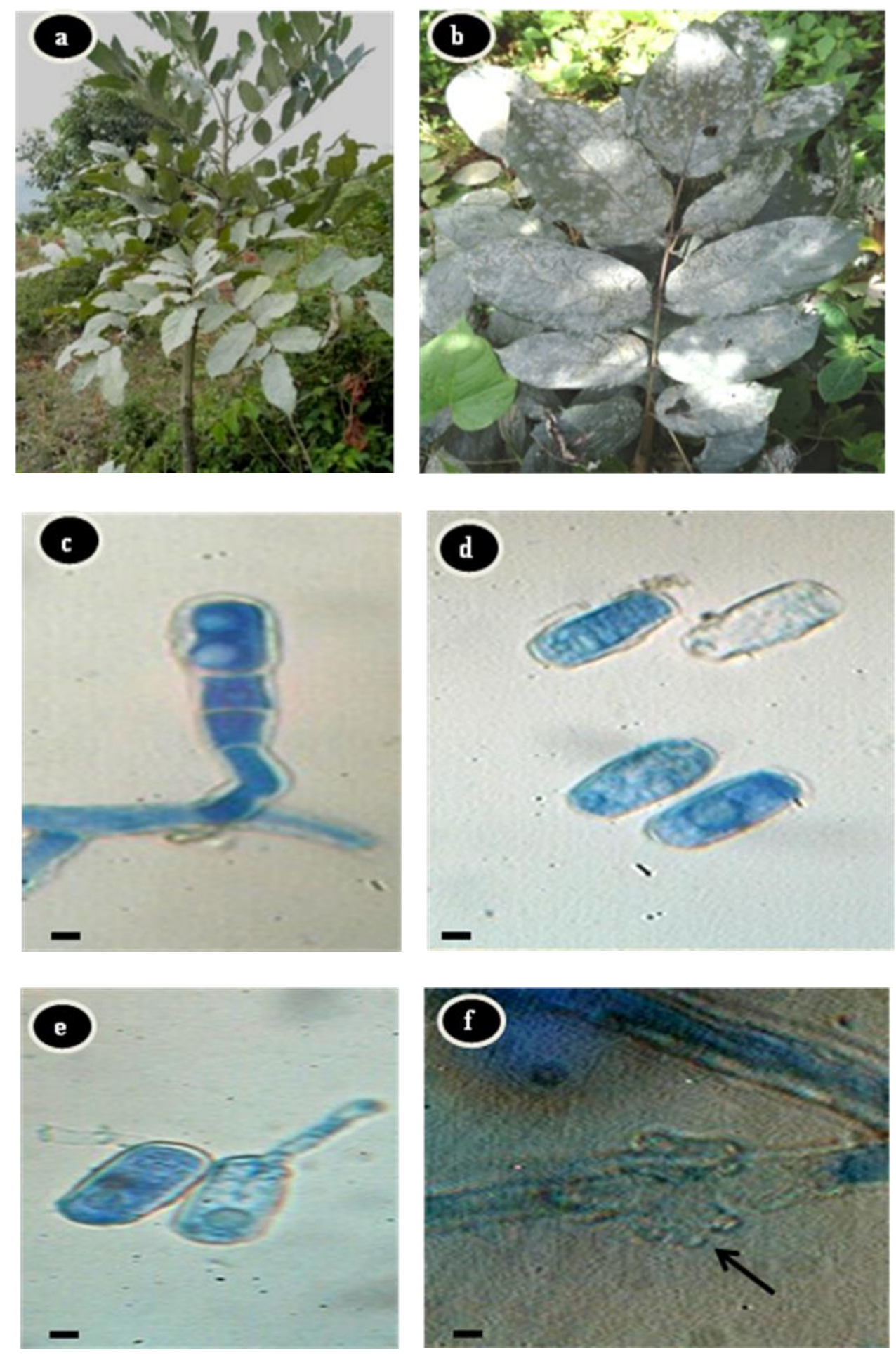

Fig 1 - Powdery mildew on Heterophragma quadriloculare. a, Infected host. b, Symptoms on adaxial surface of leaf. c, Conidiophore with single conidium. d, Conidia. e, Germinated conidia. f, Arrow indicates bilobed hyphal appresorium. - Bars $=20 \mu \mathrm{m}$.

Pseudoidium sp. (Erysiphe sp.) on $H$. quadriloculare is morphologically characterized as follows. Conidiophores $28-42 \mu \mathrm{m}$ followed by $1-2$ shorter cells or sometimes by a cell of about the same length known as foot cell, subsequent cells rarely longer than the foot cells, forming conidia singly (Fig. 1c). Conidia at the top are ovoid, up to 26-34 × 29-41 $\mu \mathrm{m}$. Fibrosin bodies absent (Fig. 1d). The conidia always germinate at the end or just below the end but never at the side (Fig. 1e). Germ tubes are more or less straight. Appressoria of the mycelia were bilobed (Fig. 1f) and that of germ tubes were lobed. Combination of these features suggests the pathogen belongs to genus 
Pseudoidium (Braun \& Cook 2012). No teleomorph stage was found to be associated with this pathogen during the present study.

\section{Discussion}

Ramkrishnan (1957) reported another powdery mildew, Phyllactinia heterophragmatis on the same host in India. However, there is no record of Pseudoidium sp. on H. quadriloculare from India or elsewhere (Bilgrami et al. 1991, Jamaludin et al. 2004, Paul \& Thakur 2006, Pande 2008, Hosagoudar \& Agarwal 2009, Braun \& Cook 2012, Mycobank 2017). Therefore, this is the first report of Pseudoidium sp. on H. quadriloculare in India.

\section{Acknowledgements}

The authors sincerely thank Prof. Uwe Braun for providing literature and valuable suggestions. Thanks are also due to Principal and Head, Department of Botany, Y. C. I. S., Satara for providing laboratory facilities.

\section{References}

Bilgrami K, Jamaluddin, MA Rizwi MA. 1991 - The Fungi of India Part III (List and References). Today and Tomorrow's Printer and Publishers, New Delhi.

Braun U, Cook RTA. 2012 - Taxonomic manual of the Erysiphales (Powdery Mildews). Fungal Biodiversity Centre (CBS Biodiversity Series No. 11), Utrecht.

Hosagoudar V, Agarwal DK. 2009 - Powdery Mildews of India - Check List. Associated Publishing Company, New Delhi.

Jamaluddin MG, Goswami, Ojha BM. 2004 - Fungi of India (1989-2001). Scientific Publishers, Jodhapur.

Mycobank 2017 - http://www.mycobank.org/Vizella 2013

Pande A. 2008 - Ascomycetes of Peninsular India. Scientific Publishers, Jodhpur.

Paul YS, Thakur VK. 2006 - Indian Erysiphaceae. Scientific Publishers, Jodhpur.

Ramkrishnan TS. 1957 - Notes on some fungi. Proceedings of the Indian Academy of Sciences Section B, 45, 176-180. 